\title{
Analisis dan Evaluasi File Storage and Backup di Diskominfo Data Center
}

\author{
ENDANG AMALIA ${ }^{1}$, RAHADIAN ADI PRATAMA ${ }^{2}$
}

\author{
1,2 Universitas Widyatama \\ Email: endang.amalia@widyatama.ac.id
}

\begin{abstract}
ABSTRAK
Bencana adalah suatu kejadian yang sangat merusak dan tidak dapat diprediksi waktu terjadinya. Suatu fasilitas yang digunakan untuk menempatkan sistem komputer dan komponen-komponen terkaitnya, seperti sistem telekomunikasi dan penyimpanan data. Menurut Badan Nasional Penanggulangan Bencana (BNPB) Indonesia sangat rentan oleh bencana dikarenakan posisi Indonesia berada diatas tiga lempeng aktif dan cincin api. Reputasi Indonesia sebagai negara rawan bencana, juga tercatat dalam laporan The Atlas of the Human Planet 2017. Datanya menunjukkan, ancaman bencana alam telah meningkat dua kali lipat dalam 40 tahun terakhir seturut meningkatnya jumlah populasi. Diskominfo Jawa Barat adalah sebuah intansi yang bertugas melaksanakan urusan pemerintah daerah Jawa Barat di bidang komunikasi dan informatika berdasarkan asas otonomi, dekonsentrasi dan tugas pembantuan. Diskomifo memiliki data center yang berguna untuk kepentingan diskominfo itu sendiri dan SKPD (Satuan Kerja Perangkat Daerah) pemerintah provinsi Jawa Barat. Sebuah data center, harus di desain sebaik mungkin untuk menghindari gangguan kerusakan akibat bencana, gangguan ataupun kesalahan yang dapat menyebabkan kerusakan dari data center itu sendiri, maka dari itu harus dapat dihindari atau diminilisir dari dampak risiko yang terjadi dan menjamin availabilitas kelangsungan bisnis organisasi apabila terjadi gangguan atau bencana. Dalam penelitian ini dilakukan analisis terkait penilaian terhadap terjadinya risiko untuk mengetahui tingkat dampak risiko. Selain itu dalam dokumen ini juga dilakukan analisis dampak bisnis untuk mengetahui prioritas dari sistem informasi yang dimiliki organisasi, agar organisasi dapat lebih mengetahui sistem informasi yang mana yang menjadi prioritas utama ketika terjadi gangguan.
\end{abstract}

Kata kunci: data center, backup, recovery, bencana, resiko, Diskominfo.

\begin{abstract}
Disaster is a very damaging and unpredictable event when it happens, threatening the facilities of computer systems and the environment, such as telecommunications systems and data storage. According to the National Disaster Management Agency (BNPB) Indonesia is very vulnerable to disasters because of the geographical characteristics. Indonesia current position is between three active plates and a ring of fire. Indonesia's reputation as a disaster-prone country is also noted in the report of The Atlas of the Human Planet 2017. The data shows that
\end{abstract}


the threat of natural disasters has doubled in the last 40 years, in line with the population growth. Diskominfo West Java is an agency that is tasked with carrying out regional government affairs in West Java in the field of communication and information technology based on the principles of autonomy, deconcentration and co-administration. Diskomifo has a data center that is useful for the benefit of the information itself and the Regional Work Unit (SKPD) of the West Java provincial government. A data center must be designed as best as possible to avoid disruption due to disasters, disturbances or errors that can cause damage to the data center itself, therefore it must be avoided or minimized from the impact of the risks that occur and guarantee the availability of the organization's business continuity if interference or disaster is occurred. In this study, an analysis was carried out related to the assessment of risk occurrence, to determine the level of the threats. In addition, in this document a business impact analysis is also carried out to determine the priorities of the information system owned by the organization, so that the organization can prioritize which information system is in the top priority when disruptions occured.

Keywords: data center, backup, recovery, disaster, risk, Diskominfo. 


\section{PENDAHULUAN}

Data Center dapat dikatakan sebagai pusat data, karena merupakan sistem yang memiliki tugas mulai dari pengumpulan data, penyimpanan data, serta pengolahan data. Data center merupakan fasilitas yang digunakan untuk menempatkan sistem komputer dan komponen terkait lainnya, seperti sistem penyimpanan data dan telekomunikasi. Data center sendiri adalah aset berharga bagi organisasi, karena didalamnya tersimpan berbagai data penting yang dimiliki oleh organisasi.

Sebuah data center, harus di desain sebaik mungkin untuk menghindari gangguan-gangguan ataupun kesalahan yang dapat menyebabkan kerusakan pada sebagian ataupun kerusakan menyeluruh pada data yang di simpan dan sistem yang dijalankan. Data center dapat diklasifikasikan sebagai salah satu pusat data atau disebut juga penyedia layanan yang berada didalam data center. Di dalam data center, pada umumnya mendukung data internal diantaranya adalah transaksi dan pengolahan, serta layanan website yang didukung dan dikelola oleh teknologi informasi.

Bencana adalah suatu kejadian yang sangat merusak dan tidak dapat diprediksi waktu terjadinya. Suatu fasilitas yang digunakan untuk menempatkan sistem komputer dan komponen-komponen terkaitnya, seperti sistem telekomunikasi dan penyimpanan data. Menurut Badan Nasional Penanggulangan Bencana (BNPB) Indonesia sangat rentan oleh bencana dikarenakan posisi Indonesia berada diatas tiga lempeng aktif dan cincin api. Reputasi Indonesia sebagai negara rawan bencana, juga tercatat dalam laporan The Atlas of the Human Planet 2017 [9]. Datanya menunjukkan, ancaman bencana alam telah meningkat dua kali lipat dalam 40 tahun terakhir seturut meningkatnya jumlah populasi. Gempa bumi sejauh ini menjadi bencana paling mengancam populasi manusia di Bumi. Banjir, menjadi bencana paling sering, paling mengancam di kawasan Asia, atau 76,9 persen populasi dunia, Namun secara garis besar BNPB mengategorikan sepuluh ancaman bencana di Indonesia yaitu, gempa bumi, tsunami, erupsi gunung api, banjir, banjir bandang, tanah longsor, kekeringan, kebakaran hutan dan lahan, cuaca ekstrem, dan gelombang ekstrem.

Dinas Komunikasi dan Informatika (DISKOMINFO) Jawa Barat adalah sebuah instansi yang bertanggung jawab atas pengolahan informasi dalam lingkungan Pemerintahan Jawa Barat. Diskominfo Provinsi Jawa Barat memiliki data center yang sangat dibutuhkan untuk pengumpulan data, penyimpanan data, serta pengolahan data. Kesiapan Diskominfo Provinsi Jawa Barat dalam menjaga data centernya agar selalu baik dan aman ketika beroperasi sangat dituntut. Maka dari itu data center yang ada pada Diskominfo Provinsi Jawa Barat untuk menjaga data centernya selalu baik terutata dalam hal File Storage dan Backup. Sehingga judul penelitian ini yaitu "ANALIS DAN EVALUASI FILE STORAGE DAN BACKUP PADA DATA CENTER DISKOMINFO PROVINSI JAWA BARAT TERHADAP RISIKO BENCANA".

\section{LANDASAN TEORI}

\subsection{E-Government}

E-Goverment adalah menggunakan teknologi informasi dan komunikasi untuk mempromosikan pemerintah yang lebih effisien dan penekanan biaya yang efektif, kemudian pasilitas layanan terhadap masyarakat umum dan membuat pemerintah lebih bertanggung jawab kepada masyarakat. Menurut United Nations "E-Government is defined as: utilizing the internet and the world-wide-web for delivering government information and services to citizens" [7]. 
Secara umum E-goverment di definisikan sebagai Pemerintahan elektronik, digital government, online government atau transformational government adalah penggunaan teknologi informasi oleh pemerintah untuk memberikan informasi dan pelayanan bagi warganya, urusan bisnis, serta hal-hal lain yang berkenaan dengan pemerintahan. EGovernment dapat diaplikasikan pada legislatif, yudikatif, atau administrasi publik, untuk meningkatkan efisiensi internal, menyampaikan pelayanan publik, atau proses kepemerintahan yang demokratis [7].

\subsection{Sistem Pemerintahan Berbasis Elektronik (SPBE)}

Sistem Pemerintahan Berbasis Elektronik (SBPE) adalah nama lain dari E-Goverment yang di gunakan oleh pemerintah di Indonesia. Sistem Pemerintahan Berbasis Elektronik (SBPE) adalah suatu sistem tata kelola pemerintahan yang memanfaatkan teknologi informasi secara menyeluruh dan terpadu, dalam pelaksanaan administrasi pemerintahan dan penyelenggaraan pelayanan publik pada badan pemerintahan [12].

Berdasarkan survei pada tahun 2016 Perserikatan Bangsa-Bangsa (PBB) mempublikasikan peringkat EGDI (E-Government Development Index) [11]. Indonesia mendapat peringkat ke 116 EGDI, turun 10 peringkat dibandingkan tahun 2014 yang menduduki peringkat ke 106. Kondisi ini masih jauh berada di bawah negara-negara di Asia Tenggara seperti Malaysia (peringkat ke-60), Filipina (peringkat ke-71), dan Brunei Darussalam (peringkat ke-83). Hal ini tentunya menjadikan suatu tantangan tersendiri bagi kita untuk dapat meningkatkan peringkat EGDI di tahun-tahun yang akan datang, di mana angka yang diperoleh merupakan cermin dari kondisi penerapan E-Goverment untuk memastikan bahwa lembaga-lembaga publik apakah sudah lebih inklusif, efektif, akuntabel dan transparan.

\subsection{Bencana}

Menurut Landesman bencana adalah kejadian apapun yang biasanya terjadi secara tiba-tiba, yang menyebabkan kerusakan, gangguan ekologis, hilangnya kehidupan manusia memburuknya kesehatan dan pelayanan kesehatan, dan melebihi kapasitas masyarakat yang terkena dampak untuk mendapatkan bantuan dari luar [3].

Sedangkan menurut Parker \& Handmer bencana adalah sebuah kejadian yang tidak biasa terjadi disebabkan oleh alam maupun ulah manusia, termasuk di dalamnya peristiwa yang disebabkan oleh kegagalan sistem teknologi yang memicu respon dari individu, komunitas, masyarakat, maupun lingkungan yang menyebabkan kerusakan besar, kerugian ekonomi, gangguan, cedera, dan/atau hilangnya nyawa [2].

Sejalan dengan Undang-undang nomor 24 tahun 2007 tentang penanggulangan bencana dan Peraturan Pemerintah nomor 21 tahun 2008 tentang penyelenggaraan penanggulangan bencana, pada bab 1 pasal 1 ayat 1 menyebutkan bencana adalah peristiwa atau rangkaian peristiwa yang mengancam dan mengganggu kehidupan dan penghidupan masyarakat yang disebabkan, baik oleh faktor alam dan/atau nonalam maupun faktor manusia sehingga mengakibatkan timbulnya korban jiwa manusia, kerusakan lingkungan, kerugian harta benda, dan dampak psikologis.

\subsection{Pemulihan Bencana (Disaster Recovery)}

Disaster Recovery adalah proses membawa organisasi atau proyek, yang telah mengalami kerusakan karena bencana, ke kondisi sebelum kecelakaan/bencana itu terjadi [4]. Disaster recovery adalah bagian dari kelangsungan bisnis (business continuity), yang didefinisikan sebagai rencana pencegahan dan rehabilitasi terhadap ancaman internal maupun eksternal organisasi untuk mengamankan integritas bisnis dan daya saing [9]. Disaster recovery terkait berbagai kegiatan, mulai dari backup data yang diambil dari sumber-sumber data, 
memperbaiki kinerja jaringan, dan membangun kembali tempat kerja utama untuk seluruh organisasi [1]. Sedangkan The National Academies menjelaskan bahwa disaster recovery meliputi dua kegiatan yaitu kegiatan jangka pendek untuk mengembalikan operasional yang kritis pada sistem fisik maupun sosial, dan kegiatan jangka panjang yang dirancang untuk memulihkan sistem-sistem tersebut dalam skala negara [5].

\section{METODOLOGI PENELITIAN}

Penelitian Terapan (applied research) merupakan metode penelitian berdasarkan tujuan yang digunakan untuk memecahkan masalah mutakhir yang dihadapi oleh manajer dalam konteks pekerjaan, yang menuntut solusi tepat waktu. Misalnya, seorang profesor universitas mungkin tertarik untuk menyelidiki faktor-faktor yang menyebabkan absensi, semata-mata sebagai minat akademik. Setelah mengumpulkan informasi tentang topik ini dari beberapa institusi dan menganalisis data, profesor tersebut mungkin menemukan faktor seperti jam kerja yang tidak fleksibel, pelatihan karyawan yang tidak memadai, dan moral yang rendah sebagai hal-hal yang memengaruhi absensi. Belakangan, seorang manajer yang menghadapi absensi karyawan dalam organisasinya dapat menggunakan informasi tersebut untuk menentukan jika faktor-faktor tersebut relevan dengan kondisi kerja di perusahaannya. Dengan demikian, penelitian yang dilakukan dengan maksud menerapkan hasil temuan untuk memecahkan masalah-masalah khusus yang saat ini sedang dialami dalam organisasi disebut penelitian terapan [6].

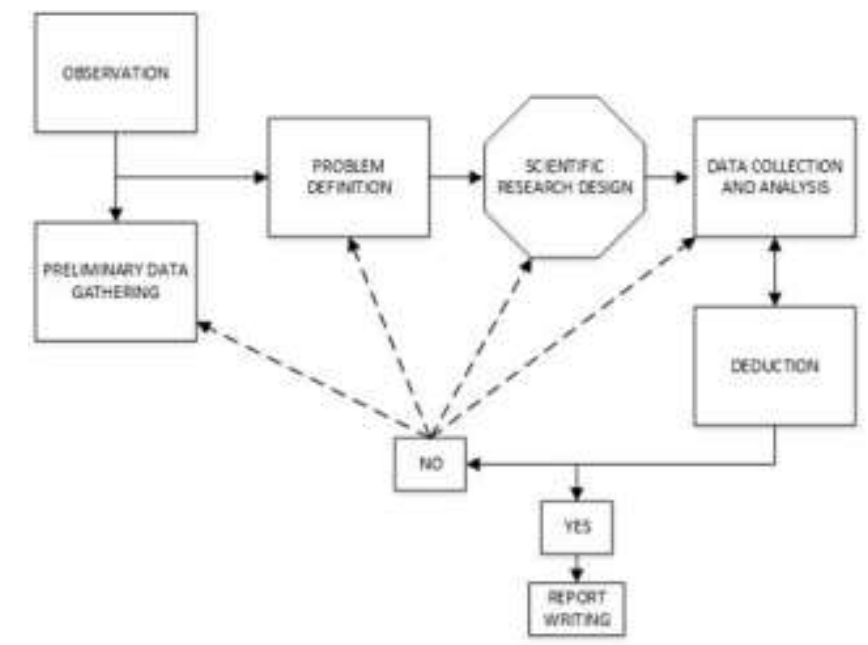

Gambar 1 Metode penelitian terapan (Sekaran, 2016)

\section{HASIL DAN ANALISIS}

Bagian ini membahas hasil dan analisa dari kajian yang dibahas dalam paper. Hasil dan analisa dituliskan dalam bentuk narasi.

\subsection{Analisis Ancaman yang Terjadi}

Tabel 1. Analisis Ancaman yang Terjadi

\begin{tabular}{|c|c|c|c|c|c|}
\hline No & Ancaman & Kejadian Ancaman & Kerentanan & Aset Penting & Konsekuensi \\
\hline 1 & $\begin{array}{c}\text { Aliran Listrik } \\
\text { PLN }\end{array}$ & $\begin{array}{c}\text { Aliran listrik dari PLN } \\
\text { terputus } \\
\text { Menyebabkan fluktuasi } \\
\text { listrik, kerusakan }\end{array}$ & $\begin{array}{c}\text { Data center } \\
\text { membutuhkan aliran } \\
\text { listrik }\end{array}$ & $\begin{array}{l}\text { Komputer, data } \\
\text { center, peralatan } \\
\text { kantor }\end{array}$ & $\begin{array}{c}\text { Kerusakan } \\
\text { perangkat } \\
\text { listrik dan } \\
\text { jaringan }\end{array}$ \\
\hline
\end{tabular}




\begin{tabular}{|c|c|c|c|c|c|}
\hline No & Ancaman & Kejadian Ancaman & Kerentanan & Aset Penting & Konsekuensi \\
\hline & & $\begin{array}{c}\text { perangkat } \\
\text { listrik/komunikasi/jaringa } \\
\mathrm{n} \text { dan pemadam } \\
\text { kebakaran }\end{array}$ & \begin{tabular}{|c|} 
Perangkat \\
listrik/komunikasi \\
/jaringan tidak dapat \\
berfungsi
\end{tabular} & & \\
\hline 2 & Gempa bumi & $\begin{array}{l}\text { Gempa bisa merusak } \\
\text { data } \\
\text { center dan infrastruktur } \\
\text { yang ada di dalamnya }\end{array}$ & $\begin{array}{c}\text { Data center terletak } \\
\text { dalam } \\
\text { gedung yang tahan } \\
\text { gempa } \\
\text { hanya sampai } 5 \text { skala } \\
\text { ritcher }\end{array}$ & $\begin{array}{l}\text { Gedung dan } \\
\text { asset } \\
\text { kantor }\end{array}$ & \begin{tabular}{|c|} 
Berhentinya \\
kegiatan \\
operasional \\
karena \\
kerusakan \\
fasilitas \\
alat-alat kantor \\
dan \\
infrastruktur \\
data \\
center
\end{tabular} \\
\hline 3 & Kebakaran & $\begin{array}{c}\text { Timbulnya api dengan } \\
\text { berbagai macam } \\
\text { penyebab/sumber api } \\
\text { baik yang berasal dari } \\
\text { hubungan arus pendek } \\
\text { ataupun sumber api } \\
\text { lainnya }\end{array}$ & $\begin{array}{c}\text { Ruangan data center; } \\
\text { dapat saja terbakar } \\
\text { atau menjadi bagian } \\
\text { dari kebakaran } \\
\text { gedung } \\
\text { Di ruang NOC data } \\
\text { center masih ada } \\
\text { material yang mudah } \\
\text { terbakar }\end{array}$ & $\begin{array}{l}\text { Gedung dan aset } \\
\text { kantor }\end{array}$ & \begin{tabular}{|c|} 
Berhentinya \\
kegiatan \\
operasional \\
karena \\
kerusakan \\
fasilitas \\
alat-alat kantor \\
dan \\
infrastruktur \\
data \\
center
\end{tabular} \\
\hline 4 & $\begin{array}{c}\text { Jaringan } \\
\text { komputer mati }\end{array}$ & $\begin{array}{c}\text { Ada peralatan jaringan } \\
\text { yang rusak. } \\
\text { Beban kerja peralatan } \\
\text { jaringan telah mendekati } \\
\text { atau melebihi } \\
\text { kemampuan peralatan } \\
\text { jaringan karena log } \\
\text { peralatan jaringan tidak } \\
\text { direview oleh admin } \\
\text { jaringan }\end{array}$ & \begin{tabular}{|c|} 
Semua peralatan \\
memiliki potensi \\
rusak \\
Beban kerja ideal \\
mempengaruhi \\
kinerja peralatan \\
jaringan, perubahan \\
yang terjadi pada log \\
peralatan jaringan \\
tidak diketahui oleh \\
admin jaringan \\
\end{tabular} & $\begin{array}{l}\text { Peralatan } \\
\text { jaringan } \\
\text { Komputer dan } \\
\text { komputer }\end{array}$ & $\begin{array}{c}\text { Kerusakan } \\
\text { perangkat } \\
\text { jaringan }\end{array}$ \\
\hline 5 & $\begin{array}{l}\text { Serangan } \\
\text { virus, } \\
\text { worm, atau } \\
\text { malware }\end{array}$ & $\begin{array}{c}\text { Adanya serangan virus, } \\
\text { worm atau malware } \\
\text { yang } \\
\text { mengeksploitasi bugs } \\
\text { pada operating system } \\
\text { atau aplikasi }\end{array}$ & $\begin{array}{l}\text { Sistem operasi } \\
\text { ataupun aplikasi yang } \\
\text { dipakai masih } \\
\text { memiliki bugs }\end{array}$ & Informasi & Kehilangan data \\
\hline 6 & $\begin{array}{c}\text { Server dan } \\
\text { Storage failure }\end{array}$ & $\begin{array}{c}\text { Beban kerja server dan } \\
\text { storage telah mendekati } \\
\text { atau melebihi } \\
\text { kemampuan server }\end{array}$ & $\begin{array}{l}\text { Server dan storage } \\
\text { memiliki batasan } \\
\text { dalam melakukan } \\
\text { aktivitas data } \\
\text { processing }\end{array}$ & $\begin{array}{l}\text { Informasi, } \\
\text { komputer }\end{array}$ & \begin{tabular}{|c|} 
Kerusakan \\
server \\
dan storage \\
sehingga \\
sistem informasi \\
tidak bisa \\
dijalankan \\
karena tidak \\
bisa \\
dibackup
\end{tabular} \\
\hline 7 & Cyber Threat & $\begin{array}{c}\text { Terdapat celah } \\
\text { keamanan }\end{array}$ & $\begin{array}{c}\text { Penyalahgunaan } \\
\text { akun karena }\end{array}$ & $\begin{array}{c}\text { Informasi, } \\
\text { reputasi }\end{array}$ & $\begin{array}{l}\text { Bocornya } \\
\text { informasi }\end{array}$ \\
\hline
\end{tabular}




\begin{tabular}{|c|c|c|c|c|c|}
\hline No & Ancaman & Kejadian Ancaman & Kerentanan & Aset Penting & Konsekuensi \\
\hline & & $\begin{array}{c}\text { di jaringan komputer } \\
\text { yang } \\
\text { diekploitasi oleh hacker } \\
\text { untuk masuk dan } \\
\text { mengambil informasi } \\
\text { rahasia organisasi }\end{array}$ & $\begin{array}{c}\text { penggunaan } \\
\text { password yang lemah }\end{array}$ & & $\begin{array}{c}\text { rahasia } \\
\text { organisasi } \\
\text { Rusaknya } \\
\text { reputasi } \\
\text { organisasi }\end{array}$ \\
\hline 8 & $\begin{array}{l}\text { Kerusuhan } \\
\text { Massa }\end{array}$ & $\begin{array}{c}\text { Kerusuhan massa dapat } \\
\text { merusak Infrastrukur- } \\
\text { infrastruktur yang } \\
\text { dimiliki Diskominfo }\end{array}$ & $\begin{array}{c}\text { Data center terletak } \\
\text { di gedung Diskominfo } \\
\text { lantai } 3\end{array}$ & $\begin{array}{l}\text { Gedung dan } \\
\text { asset } \\
\text { kantor }\end{array}$ & $\begin{array}{c}\text { Kerusakan pada } \\
\text { gedung dan } \\
\text { infrastruktur } \\
\text { Diskominfo } \\
\end{array}$ \\
\hline 9 & Human Error & $\begin{array}{c}\text { Human error dapat } \\
\text { menyebabkan kerusakan } \\
\text { pada infrastruktur data } \\
\text { Center }\end{array}$ & \begin{tabular}{|c|} 
Belum ada SOP yang \\
jelas terkait \\
peraturan di dalam \\
ruangan data center
\end{tabular} & Data center & $\begin{array}{l}\text { Kerusakan pada } \\
\text { perangkat data } \\
\text { center }\end{array}$ \\
\hline
\end{tabular}

\subsection{Evaluasi dan Rekomendasi}

Tabel 2. Evaluasi dan Rekomendasi

\begin{tabular}{|c|c|c|c|c|c|}
\hline No & Ancaman & \begin{tabular}{|c|} 
Nilai \\
Kecenderung \\
an
\end{tabular} & $\begin{array}{c}\text { Nilai } \\
\text { Dampak }\end{array}$ & Nilai Resiko & Kontrol yang Harus Disediakan \\
\hline 1 & $\begin{array}{c}\text { Aliran Listrik } \\
\text { PLN }\end{array}$ & Moderate & High & Moderate & $\begin{array}{c}\text { Menyediakan arus listrik dengan } \\
\text { sumber yang berbeda } \\
\text { Menyediakan UPS dengan spesifikasi } \\
\text { yang cukup agar dapat membantu } \\
\text { ketika pemadaman listrik terjadi }\end{array}$ \\
\hline 2 & Gempa bumi & Low & Very High & Moderate & $\begin{array}{c}\text { Kontruksi ruangan data center harus } \\
\text { dapat menahan gampa serta } \\
\text { reruntuhannya. }\end{array}$ \\
\hline 3 & Kebakaran & Low & Very High & Moderate & $\begin{array}{l}\text { Memasang alat deteksi api dan } \\
\text { pemadam otomatis } \\
\text { Masih ada beberapa bahan yang } \\
\text { mudah terbakar } \\
\text { Memasang pendeteksi api otomatis di } \\
\text { NOC }\end{array}$ \\
\hline 4 & $\begin{array}{c}\text { Jaringan } \\
\text { komputer mati }\end{array}$ & Low & High & Low & $\begin{array}{c}\text { Menerapkan Network monitoring } \\
\text { tools untuk mengetahui peralatan } \\
\text { yang bermasalah }\end{array}$ \\
\hline 5 & $\begin{array}{l}\text { Serangan } \\
\text { virus, } \\
\text { worm, atau } \\
\text { malware }\end{array}$ & High & Very High & Very High & $\begin{array}{c}\text { Menerapkan patching terhadap } \\
\text { sistem operasi } \\
\text { secara berkala } \\
\text { Antivirus yang terinstal sudah } \\
\text { terupdate } \\
\text { Menerapkan email Scanning dan } \\
\text { email filtering sebelum diproses oleh } \\
\text { Email Server } \\
\end{array}$ \\
\hline 6 & $\begin{array}{c}\text { Server dan } \\
\text { Storage failure }\end{array}$ & Moderate & High & Moderate & $\begin{array}{c}\text { Menerapkan Server Monitoring tool } \\
\text { untuk memberikan alert secara } \\
\text { otomatis jika server bermasalah } \\
\text { Terdapat server mirroring untuk } \\
\text { meletakkan data penting di gedung } \\
\text { lain }\end{array}$ \\
\hline
\end{tabular}




\begin{tabular}{|c|c|c|c|c|c|}
\hline 7 & Cyber Threat & High & Very High & Very High & $\begin{array}{c}\text { Penggunaan password dengan } \\
\text { kombinasi angka } \\
\text { huruf besar dan huruf kecil dan } \\
\text { prosedur penggantian password } \\
\text { secara berkala } \\
\text { Logging, monitoring, pemasangan } \\
\text { firewall terupdate }\end{array}$ \\
\hline 8 & $\begin{array}{c}\text { Kerusuhan } \\
\text { Massa }\end{array}$ & Low & High & Low & $\begin{array}{c}\text { Memiliki sistem keamanan yang baik } \\
\text { dari segi SDM ataupun infrastruktur }\end{array}$ \\
\hline 9 & Human Error & Moderate & Moderate & Moderate & $\begin{array}{c}\text { Memberikan pelatihan yang tepat } \\
\text { bagi karyawan agar dapat } \\
\text { menangkap kesalahan lebih awal } \\
\text { sebelum terjadi }\end{array}$ \\
\hline
\end{tabular}

\section{KESIMPULAN}

Dari penelitian yang telah dilakukan di Diskominfo Provinsi Jawa Barat dapat di tarik kesimpulan:

1. Dengan menentukan langkah-langkah yang terpat dalam operasioanal data centemya Diskominfo Provinsi Jawa Barat dapat menghadapi ancaman risiko bencana pada data center yang dimilikinya, sehingga Diskominfo Provinsi Jawa Barat dapat menentukan langkah yang harus dilakukan agar kondisi data center yang di miliki akan selalu sesuai dan aman terhadap risiko bencana.

2. Evualuasi dan solusi yang di berikan adalah memberikan identifikasi kontrol pencegahan untuk untuk mengurangi tingkat risiko yang terjadi terhadap aset-aset yang ada di data center dan juga di lakukan pemilihan metode backup yang di sesuaikan dengan prioritas masing-masing sistem informasi.

\section{DAFTAR RUJUKAN}

[1] Clark, P. (2010). Contingency planning and strategies. Kennesaw State.

[2] Handmer, P. \&. (1992). Hazard management and emergency. London.

[3] Landesman. (2001). Public health management of disasters: The practice. Washington, DC.

[4] Nigg, J. M. (1995). Wellington after the quake: The challenge of rebuilding. Wellington, New Zealand: the Earthquake Commission.

[5] Ramesh R. Rao, J. E. (2007). Improving Disaster Management: The Role Of. Washington D.C. United States: The National Academies.

[6] Sekaran, U. (2016). Research Methods for Business: A Skill-Building Approach Vol.4.

[7] Sihwi, S. W. (2009). Pengembangan Process Maturity Framework Pada E-Government di Indonesia. Jakarta, Indonesia: Universitas Indonesia.

[8] Anthopoulos, L. G.-P. (2012). An effective disaster recovery model for construction projects. Crete, Greece.

[9] PESARESI Martino, E. D. (2017). Atlas of the Human Planet 2017: Global Exposure to Natural Hazards. Publications Office of the European Union.

[10] Sosiawan, E. A. (2008). Tantangan Dan Hambatan Dalam Implementasi E-Government di Indonesia. Yogyakarta, Indonesia: UPN Veteran.

[11] BPPTIK. (2016). Peringkat Egovernment Indonesia berdasarkan survey PBB. https://bpptik.kominfo.go.id/2016/09/09/2190/inilah-peringkat-e-government-indonesiaberdasarkan-survei-pbb-2016/. 
[12] Tayyiba, P. S. (2017, Mei 31). Pembahasan Rancangan Perpres SPBE. Retrieved from http://www.wantiknas.go.id/2017/07/18/peran-kepemimpinan-cio-dalam-mewujudkane-government-terpadu/ 